\title{
Lietuvos indėlis ị tarptautines operacijas: esama situacija ir galimi scenarijai ${ }^{* *}$
}

\begin{abstract}
Straipsnyje pateikiama informacija apie Lietuvos karinị indèli $\mathfrak{j}$ tarptautinio saugumo ir stabilumo užtikrinimą - Lietuvos Respublikos karių dalyvavimą tarptautinèse operacijose ir Europos Sąjungos mokymo misijose 2004-2017 m. Jame trumpai supažindinama su teisiniais dalyvavimo tarptautinèse operacijose pagrindais ir pristatomi esminiai apribojimai, darantys įtaką Lietuvos karių, dalyvaujančiu tarptautinèse operacijose, skaičiui. Straipsnyje išsamiai analizuojamas 2004-2017 m. LK karių skaičiaus pokytis NATO, Europos Sąjungos, Jungtinių Tautų ir kitose strateginių partnerių vykdytose tarptautinèse operacijose, Lietuvos karinis indèlis pateikiamas bendrame NATO, ES ir JT vykdomų karinių operacijų kontekste, išskiriamos Lietuvos karių dalyvavimo tarptautinėse operacijose pokyčio tendencijos. Atsižvelgiant ị skiriamų ir turimų LR krašto apsaugos sistemai išteklių (finansinių ir žmogiškujjų) pokytį, taip pat ị LR Seimo išreikštos politinès valios dalyvauti tarptautinèse operacijose pokytị, iš istorinès perspektyvos bandoma atrasti galimą jų ryšs̆ ir ịtaką Lietuvos kariniam indèliui i tarptautines operacijas ateityje.
\end{abstract}

\section{lvadas}

Lietuvos Respublikos karių ir civilių krašto apsaugos sistemos tarnautojų dalyvavimas NATO, Europos Sąungos, Jungtinių Tautų, kitose tarptautinèse operacijose ir ES mokymo misijose leidžia ịgyvendinti Lietuvos Respublikos užsienio politikos interesus, formuoti teigiamą Lietuvos Respublikos ịvaizdi tarptautinèje bendruomenèje, prisidèti prie tarptautinių organizacijų pastangų užtikrinti taiką bei stabilumą ir igyvendinti LR nacionalinės saugumo strategijos uždavinius ir prioritetus. $2004 \mathrm{~m}$. Lietuvai tapus visateise NATO, Europos Sąjungos nare ir siekiant užtikrinti prisiimtų tarptautinių ịsipareigojimų iggvendinimą, šalies indèlis užtikrinant tarptautinị saugumą ir stabilumą,

\footnotetext{
"Kmd. Itn. Gintas Gumbrys - Lietuvos Respublikos krašto apsaugos ministerijos Tarptautinių ryšiu ir operacijų departamento Tarptautinių operacijų skyriaus vyriausiasis specialistas. Adresas korespondencijai: Totoriu g. 25, 01121 Vilnius, tel. (8 5) 273 5633, el. p. gintas.gumbrys@kam.lt.

" Šiame straipsnyje pateikti vertinimai ir mintys yra be išimčiu tik autoriaus ir jokiomis aplinkybėmis negali būti vertinamos kaip Lietuvos Respublikos krašto apsaugos ministerijos ir jos padalinių oficiali pozicija.
} 
skiriant karius ir civilius krašto apsaugos sistemos tarnautojus i tarptautines operacijas ir ES mokymo misijas, pasidare ypač svarbus. Kaip yra pasakęs LR krašto apsaugos ministras R. Karoblis: „Jei norime, kad mus kažkas gintų, mes taip pat turime prisidèti prie kitu gynybos, kitų interesų."

2004-2017 m. sudètingejjanti geopolitinè saugumo situacija, išryškejjusios naujo pobūdžio grèsmès tarptautiniam saugumui ir stabilumui, didejantis krizių apimtų regionų skaičius lėmé ne tik NATO, Europos Sajungos, Jungtinių Tautų, kitų organizacijų, šalių vykdomų tarptautinių operacijų skaičiaus didèjimą, bet ir šių operacijų pobūdžio ir joms skirtų užduočių pokyčius. Tarptautinès bendruomenès indèlis siekiant užtikrinti situacijos stabilizavimą Afganistane, Irake, pagalbos teikimas kitiems krizių ištiktiems regionams Afrikoje ir Azijoje, ES karinès mokymo misijos, kova su piratavimu ir ginkluotais plèšimais jūroje, globalios koalicijos kova prieš teroristinę organizaciją „Islamo valstybë", tarptautinè parama Gruzijai ir Ukrainai, kova siekiant suardyti nelegalios migracijos tinklus Viduržemio jūroje rodo užduočių, keliamų tarptautinèms karinèms operacijoms ir mokymo misijoms, ịvairumą. Dèl šios priežasties svarbu peržvelgti, kaip Lietuvos kariuomene buvo pasiruošusi šiems iššūkiams ir kiek Lietuva prisidejjo prie tarptautinès bendruomenès pastangų, siekiant užtikrinti tarptautinị saugumą ir stabilumą, siųsdama Lietuvos karius dalyvauti tarptautinėse operacijose ir mokymo misijose.

Išsami analizė apie faktinį Lietuvos karių indèli $\mathfrak{i}$ tarptautines operacijas ir ES mokymo misijas, esminius pokyčius bei tendencijas iki šiol nebuvo atlikta. Vienintelis, daugiau faktinès informacijos pateikiantis leidinys - Lietuvos Respublikos krašto apsaugos ministerijos 2014 m. išleista apžvalginè knyga „Taikos sargyboje: Lietuvos kariai tarptautinèse operacijose 1994-2014 m.“ Nors informacija apie karių dalyvavimą tarptautinėse operacijose periodiškai atnaujinama LR krašto apsaugos ministerijos ${ }^{2}$, Lietuvos kariuomenès Gynybos štabo $^{3}$ interneto svetainèse, atviruose informaciniuose šaltiniuose, tačiau jie taip pat neatspindi esminių pokyčių ir tendencijų.

Straipsnio tikslas - apžvelgti Lietuvos karių dalyvavimo tarptautinèse operacijose ir ES mokymo misijose indèli, jo pokyti 2004-2017 m. ir pateikti galimas dalyvavimo tarptautinèse operacijose ar mokymo misijose perspektyvas. Šio darbo pagrindiniai uždaviniai: a) apžvelgti Lietuvos karių dalyvavimo tarptautinėse operacijose ir ES mokymo misijose teisinius pagrindus ir

\footnotetext{
${ }^{1}$ LR krašto apsaugos ministras Raimundas Karoblis, 2017-10-12, http://kam.lt/lt/naujienos_874/aktualijos_875/seimas_apsiprende_del_lietuvos_kariu_dalyvavimo_tarptautinese_operacijose_2018-2019_metais.html.

${ }^{2} \mathrm{http} / / /$ kam.lt/download/54136/lietuvos\%20dalyvavimas\%20tarptautinėse\%20operacijose.pdf.

${ }^{3} \mathrm{http} / / / \mathrm{www} . g y n y b o s s t a b a s .1 / / \mathrm{lt} / \mathrm{vykdomos}-\mathrm{to} /$
} 
esminius apribojimus; b) pateikti Lietuvos karių indèli ir jo pokyčius ị NATO, Europos Sąjungos, Jungtinių Tautų ir kitų strateginių partnerių vykdytas tarptautines operacijas ar mokymo misijas 2004-2017 m.; c) ịvertinti galimą LR krašto apsaugos sistemai skiriamų išteklių įtaką Lietuvos karių ir civilių KAS tarnautojų dalyvavimui tarptautinėse operacijose ir mokymo misijose.

Šiame straipsnyje pateikta faktinè informacija apie LK karių dalyvavimą tarptautinèse operacijose galètų net tik paskatinti akademinę bendruomenę atlikti išsamesnius tyrimus šioje srityje, tačiau ir pagyvinti diskusijas politiniu-strateginiu lygmeniu ịtraukiant politikus, mokslininkus, aukšto rango karininkus, prieš priimant sprendimą dèl Lietuvos karių dalyvavimo tarptautinèse operacijose. Viena iš galimų mokslinio tyrimo krypčių kokybinè analizè dèl ịtakos grupių (pvz.: visuomenès, politikų, KAS civilių, KAS vadovybès, LK aukščiausio rango karininkų, Gynybos štabo) vaidmens ir reikšmès priimant Lietuvai sprendimus dèl LK karių dalyvavimo tarptautinèse operacijose. Be to, ateityje vertinant Lietuvos indeli $\mathfrak{i}$ tarptautines operacijas ir ES mokymo misijas, būtu galima atlikti ne tik kiekybinio pokyčio, išreikšto LK karių skaičiumi tarptautinèse operacijose, analizę, tačiau ir kokybinio indèlio pokyčio vertinimą. Išsamesnè pajègumų, siunčiamų i tarptautinę operaciją, analizè, ar kariams skirtų užduočių, patikètų pareigų, jų atliktų užduočių tarptautinèse operacijose ịvertinimų pokyčiai suteiktų galimybę kur kas objektyviau ir išsamiau išanalizuoti Lietuvos faktinị-kokybinị indèlị $\mathfrak{i}$ tarptautinio saugumo ir stabilumo užtikrinimą. Taip pat pažymètina, kad nepakankamai išanalizuota ir trūksta informacijos apie Lietuvos indèlị $\mathfrak{i}$ civilines tarptautines operacijas ar ES mokymo misijas, skiriant civilius krašto apsaugos sistemos ar valstybès tarnautojus, kurių svarba reaguojant ị iššūkius krizių regionuose sparčiai didejja.

\section{Lietuvos dalyvavimas tarptautinèse operacijose}

\subsection{Dalyvavimo tarptautinèse operacijose pagrindas}

Lietuvos Respublika (toliau - LR), łgyvendindama užsienio politiką, vadovaujasi visuotinai pripažintais tarptautinès teisès principais ir normomis, siekia užtikrinti šalies saugumą ir nepriklausomybę, piliečiu gerovę ir pagrindines jų teises bei laisves, prisideda prie teise ir teisingumu pagrịstos 
tarptautinès tvarkos kūrimo ${ }^{4}$. Vienas iš LR užsienio politikos uždavinių - aktyviai prisidèti prie tarptautinès bendrijos pastangų užkirsti kelią terorizmui, konfliktams, ịvesti, atkurti ir palaikyti taiką krizių paveiktuose regionuose ${ }^{5}$. Dalyvaudama tarptautinių institucijų ir organizacijų veikloje, Lietuva taip pat dalyvauja tarptautinėse humanitarinėse, reagavimo ị krizes bei taikos palaikymo misijose ir kitose akcijose ${ }^{6}$.

Lietuva, formuodama ir igyvendindama nacionalinio saugumo politiką, prisideda prie tarptautinès taikos ir visaapimančio saugumo, pagrįsto demokratinemis vertybèmis, teise ir teisingumu, palaikymo ${ }^{7} .2017 \mathrm{~m}$. atnaujintoje Nacionalinio saugumo strategijoje taip pat ịtvirtintas vienas iš LR nacionalinio saugumo politikos prioritetų ir ilgojo ir vidutinio laikotarpių uždavinių - aktyvus dalyvavimas stiprinant tarptautinị saugumą ir stabilumą ${ }^{8}$. Šioje strategijoje numatyta, kad veikdama kaip aktyvi ir atsakinga tarptautinès bendruomenès narè, LR prisidès prie tarptautinès bendrijos pastangų palaikyti taiką ir stabilumą pasaulyje, užkirsti kelią tarpvalstybiniams ir etniniams konfliktams, spręsti užsitęsusius konfliktus, kovoti su tarptautiniu terorizmu ir organizuotu nusikalstamumu, pagal galimybes civiliniais ir kariniais pajègumais prisidès prie NATO, ES ir kitų tarptautinių organizacijų ir šiam tikslui buriamų koalicijų tarptautinių operacijų ir misijų

LR Seimas priima sprendimą panaudoti ginkluotąsias pajègas, kai prireikia ginti Tẻvynę arba vykdyti Lietuvos valstybės tarptautinius įsipareigojimus $^{10}$. Sprendimus dèl Lietuvos kariuomenès vienetų dalyvavimo tarptautinèse karinèse operacijose priima Respublikos Prezidentas ir Seimas Konstitucijos ir ịstatymų nustatyta tvarka ${ }^{11}$. Pagrindiniame Lietuvos karių ir civilių KAS tarnautojų dalyvavimą tarptautinėse operacijose reglamentuojančiame ịstatyme nustatyta, kad sprendimą dèl LR karinių vienetų išvykimo ir panaudojimo kitos operacijos tikslais kitų valstybių teritorijose priima Lietuvos Respublikos Seimas, Respublikos Prezidento teikimu priimdamas nutarimą ${ }^{12}$. Pasiūlymus dèl LR karinių vienetų dalyvavimo tarptautinèse operacijose Prezidentui teikia

\footnotetext{
${ }^{4}$ Lietuvos Respublikos Konstitucija (Lietuvos Respublikos piliečių priimta 1992 m. spalio 25 d. referendume), 135 str.

${ }^{5}$ Lietuvos Respublikos nacionalinio saugumo pagrindų ịstatymas (1996 m. gruodžio 19 d. Nr. VIII-49), I dalis, V skirsnis.

${ }^{6}$ Ten pat, II dalis, 10 skyrius, II skirsnis.

${ }^{7}$ Nacionalinio saugumo strategija (2017 m. sausio $1 \mathrm{~d}$. Nr. XIII-202), I skyrius, 3 punktas.

${ }^{8}$ Ten pat, V skyrius, 18.6 punktas.

${ }^{9}$ Ten pat, V skyrius, 18.6 .2 papunktis.

${ }^{10}$ Lietuvos Respublikos Konstitucija (2 išnaša), 142 str.

${ }^{11}$ Lietuvos Respublikos nacionalinio saugumo pagrindų įstatymas ( 3 išnaša), I dalis, 8 skyrius.

${ }^{12}$ Lietuvos Respublikos tarptautinių operacijų, pratybų ir kitų karinio bendradarbiavimo renginių itstatymas.
} 
krašto apsaugos ministras kartu su užsienio reikalų ministru ${ }^{13}$.

Pažymetina, kad taikos metu vienas iš pagrindinių Lietuvos kariuomenės uždavinių - palaikyti kovinę parengtị, rengtis tarptautinėms operacijoms ir dalyvauti jose ${ }^{14}$, o svarbiausias kariuomenès vado uždavinys - tinkamai rengti kariuomenę ginkluotai valstybès gynybai, užtikrinant jos sąveiką su kitų NATO valstybių ginkluotosiomis pajègomis ir dalyvavimą tarptautinèse operacijose $^{15}$.

\subsection{4-2017 m. Lietuvos Respublikos Seimo nutarimai dèl dalyvavimo tarptautinèse operacijose}

Dalyvavimas tarptautinėse operacijose - tai priemoné igyvendinti Lietuvos įsipareigojimus tarptautiniam saugumui ir stiprinti NATO kolektyvinę gynybą, Europos Sąjungos bendrojo saugumo ir gynybos politiką, Jungtinių Tautu taikos palaikymo pastangas, daugiašalị ir dvišalị karinị bendradarbiavimą $^{16}$. Faktinis Lietuvos dalyvavimas tarptautinèse operacijose ir indèlis $\mathfrak{i}$ jas priklauso nuo saugumo situacijos, NATO, Europos Sąjungos, sąjungininkų vykdomų tarptautinių operacijų, strateginių partnerių išreikšto poreikio ir Lietuvos galimybių ${ }^{17}$.

LR Seimas, priimdamas nutarimą dèl Lietuvos Respublikos karinių vienetų dalyvavimo tarptautinėse operacijose, išreiškia šalies politinę valią ir suteikia teisę Lietuvos kariams ir civiliams KAS tarnautojams dalyvauti tarptautinèse operacijose. Suteikdamas teisę kariams dalyvauti tarptautinėse operacijose ar ES mokymo misijose, LR Seimas minètu nutarimu nustato ne tik konkrečias tarptautines operacijas ar dalyvavimo tarptautinėse operacijose regionus, valstybes, bet ir leidžiamus didžiausius karių ir civilių KAS tarnautojų, galinčiu dalyvauti tarptautinèje operacijoje, skaičius. Dèl šios priežasties LR Seimo nutarimai dèl Lietuvos Respublikos karinių vienetų dalyvavimo tarp-

\footnotetext{
${ }^{13}$ Krašto apsaugos sistemos organizavimo ir karo tarnybos įstatymas (1998 m. gegužès 5 d. Nr. VIII-723), II skirsnis, 10 str., 2 p., 9 papunktis.

${ }^{14}$ Ten pat, III skirsnis, 12 str. 1 p.

${ }^{15}$ Krašto apsaugos sistemos organizavimo ir karo tarnybos įstatymas (11 išnaša), III skirsnis, 13 str. 6 p. ${ }^{16}$ Lietuvos Respublikos krašto apsaugos ministerija (2017). LR Seimo nutarimo projekto dẻl Lietuvos karių dalyvavimo tarptautinèse operacijose pristatymas LR Seime. Krašto apsaugos ministro Raimundo Karoblio kalba. http://kam.lt/lt/naujienos_874/aktualijos_875/seimas_apsiprende_del_lietuvos_kariu_dalyvavimo_ tarptautinese_operacijose_2018-2019_metais.html, 2017-10-12 19.24 val.

${ }^{17}$ Lietuvos Respublikos krašto apsaugos ministerija (2017), Tarptautinis bendradarbiavimas, Tarptautinès operacijos ir misijos, http://kam.lt/lt/tarptautinis_bendradarbiavimas/tarptautines_operacijos.html, https://www.delfi.lt/news/daily/lithuania/seimas-apsisprende-del-lietuvos-kariu-dalyvavimo-tarptautinese-operacijose.d?id=76032645, 2017-10-12 19.25 val.
} 
tautinèse operacijose gali būti vertinami kaip pagrindiniai teisiniai norminiai aktai, suteikiantys teisinį pagrindą ir nustatantys apribojimus LK kariams ir civiliams KAS tarnautojams dalyvauti tarptautinèse operacijose.

2004-2017 m. LR Seimo nutarimų dèl Lietuvos karių ir civilių KAS tarnautojų dalyvavimo tarptautinėse operacijose suvestinè pateikta 1 lentelèje.

1 lentelè. LR Seimo nutarimai dèl dalyvavimo tarptautinèse operacijose.

\begin{tabular}{|c|c|c|c|}
\hline $\begin{array}{l}\text { Eil. } \\
\mathrm{nr} .\end{array}$ & LR Seimo nutarimas & Galioja iki & $\begin{array}{l}\text { Metai ir leidžiamas } \\
\text { didžiausias kariụ ir civiliụ } \\
\text { KAS tarnautoju, galinčiụ } \\
\text { dalyvauti tarptautinèje } \\
\text { operacijoje, skaičius }\end{array}$ \\
\hline 1. & 2004 m. rugsèjo 29 d. Nr. IX-2468 & $2005-12-31$ & 2005 m. iki 330 \\
\hline 2. & 2005 m. birželio 9 d. Nr. X-240 & $2007-12-31$ & $\begin{array}{l}2005 \text { m. iki } 350 \\
2006-2007 \text { m. iki } 420\end{array}$ \\
\hline 3. & 2007 m. birželio 14 d. Nr. X-1184 & 2010-12-31 & 2008-2010 m. iki 420 \\
\hline 4. & 2009 m. lapkričio 19 d. Nr. XI-494 & 2013-12-31 & 2011-2013 m. iki 420 \\
\hline 5. & 2012 m. birželio 12 d. Nr. XI-2059 & 2013-12-31 & 2012-2013 m. iki 355 \\
\hline 6. & 2013 m. balandžio 23 d. Nr. XII-249 & 2015-12-31 & 2014-2015 m. iki 265 \\
\hline 7. & 2014 m. kovo 18 d. Nr. XII-788 & 2014-06-01 & 2014 m. iki 275 \\
\hline 8. & 2015 m. gruodžio 22 d. Nr. XII-2232 & $2017-12-31$ & 2016-2017 m. iki 130 \\
\hline 9. & 2016 m. birželio 29 d. Nr. XII-2541 & $2017-12-31$ & 2016-2017 m. iki 175 \\
\hline 10. & 2017 m. birželio 28 d. Nr. XIII-525 & 2017-12-31 & 2017 m. iki 235 \\
\hline
\end{tabular}

LR Seimo nutarimais nustatyto didžiausio karių ir civilių KAS tarnautojų, galinčių dalyvauti tarptautinèse operacijose, skaičiaus pokytis 2004-2017 m. pateiktas 1 pav. Pažymètina, kad didžiausias LK karių ir civilių KAS tarnautojų, galinčiu dalyvauti tarptautinėse operacijose, skaičius LR Seimo nutarimais nustatytas 2006-2012 m. (420 karių), o mažiausias - 2015-2016 m. (130 karių). LR Seimo nutarimais nustatytam rekordiniam LK karių ir civilių KAS tarnautojų, galinčių dalyvauti tarptautinėse operacijose, skaičiui 2006-2012 m. ịtakos neturejjo ir tai, kad LR krašto apsaugos sistemai skiriamas finansavimas tuo pat metu krito ị rekordines žemumas (2006 m. - 1,16, o 2012 m. - 0,77 proc. BVP). 


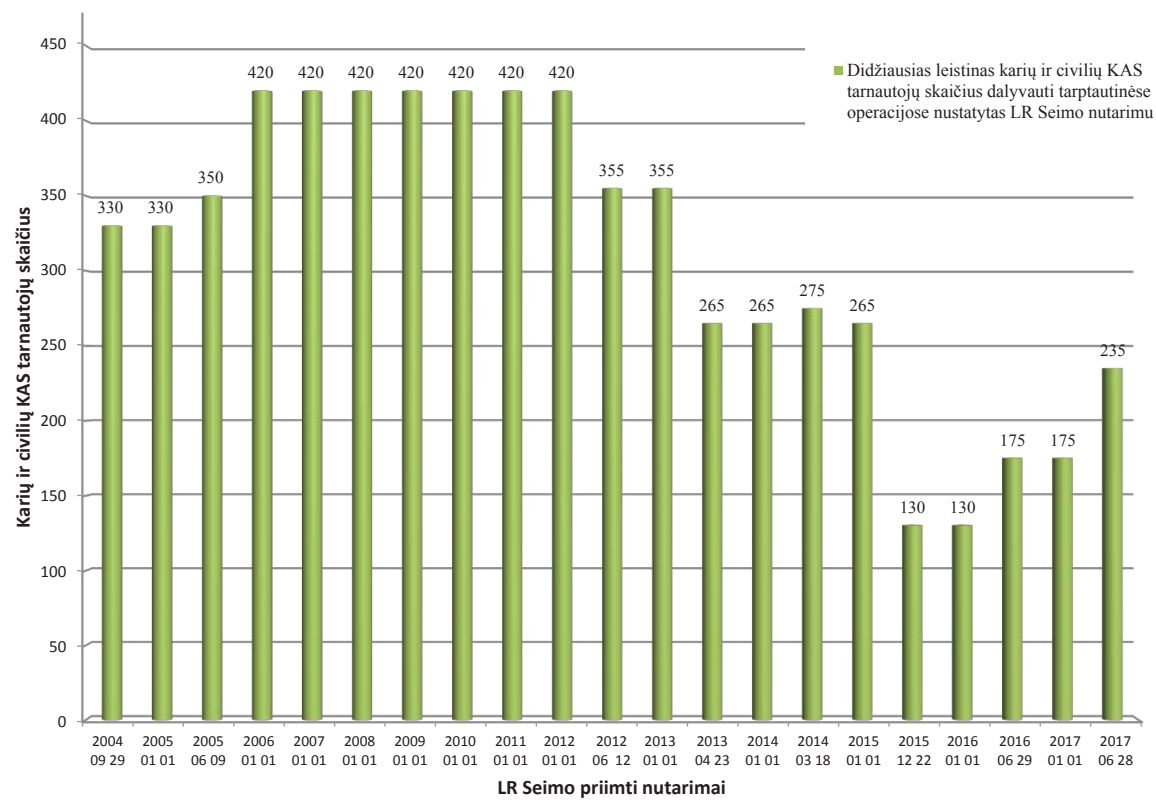

1 pav. Didžiausias leidžiamas dalyvauti tarptautinèse operacijose LK karių ir civilių KAS tarnautojų skaičius

\subsection{Lietuvos karių dalyvavimas tarptautinèse operacijose}

\subsubsection{Lietuvos indèlio ị NATO operacijas 2004-2017 m. apžvalga}

Iki 2014 m. 97 proc. Lietuvos kariuomenès karių, skirtų dalyvauti tarptautinèse operacijose, dalyvavo NATO operacijose, 2 proc. - Jungtinių Tautų ir 1 proc. - Europos Sajungos operacijose ${ }^{18}$. Nuo Lietuvos kariuomenès karių dalyvavimo NATO operacijose pradžios $1996 \mathrm{~m}$. iki $2014 \mathrm{~m}$. NATO operacijose dalyvavo daugiau kaip 4600 karių $^{19}$. Lietuvos karių skaičiaus NATO operacijose metinis vidurkis, be Specialiųjų operacijų pajėgų, pateiktas 2 pav. Didžiausias Lietuvos indèlis minètu laikotarpiu i NATO operacijas buvo Afganistane. Afganistano Goro provincijos atkūrimo grupé veiklą vykdè nuo 2005 m. iki 2013 m. ir jos dydis buvo apie 150 LK karių ${ }^{20}$ - didžiausias Lietuvos karių kontin-

\footnotetext{
${ }^{18}$ Lietuvos Respublikos krašto apsaugos ministerija (2014). „Taikos sargyboje: Lietuvos kariai tarptautinèse operacijose 1994-2014 m.“, p. 35.

${ }^{19}$ Ten pat, p. 37.

${ }^{20}$ Ten pat, p. 37.
} 
gentas Afganistane. Lietuvos vadovaujamoje Provincijos atkūrimo grupeje minètu laikotarpiu iš viso tarnavo apie 2500 Lietuvos karių. Lietuva į NATO KFOR operaciją Kosove iki 2009 m. pabaigos skyrẻ būrio dydžio vienetą, kuris užduotis vykdè Lenkijos bataliono sudètyje. $2005 \mathrm{~m}$. Lietuvos kariuomenès vandens valymo vienetas buvo dislokuotas Pakistane kaip NATO greitojo reagavimo pajėgų sudedamoji dalis ${ }^{21}$. Pavieniai Lietuvos kariai dalyvavo NATO mokymo misijoje Irake iki 2011 m. pabaigos, o nuo 2014 m. - kovos su piratavimu operacijoje „Vandenyno skydas“ ir oro gynybos operacijoje Turkijoje. 2013 m. Lietuvos kariams baigus dalyvavimą NATO Tarptautinių saugumo paramos pajègų Goro provincijos atkūrimo grupès veikloje ir perdavus stovyklos infrastruktūrą Afganistano nacionalinèms saugumo pajegoms, o NATO transformavus šią operaciją $\mathfrak{i}$ „Tvirta parama“, gerokai sumažèjo ir Lietuvos karių, dalyvaujančių NATO operacijose, metinis vidurkis.

2017 m. Lietuvos indèlis ị NATO operaciją Afganistane „Tvirta parama“ padidejo nuo 21 iki 29 LK karių, NATO KFOR operacijoje Kosove buvo išlaikytas 1 Lietuvos karys ${ }^{22}$.

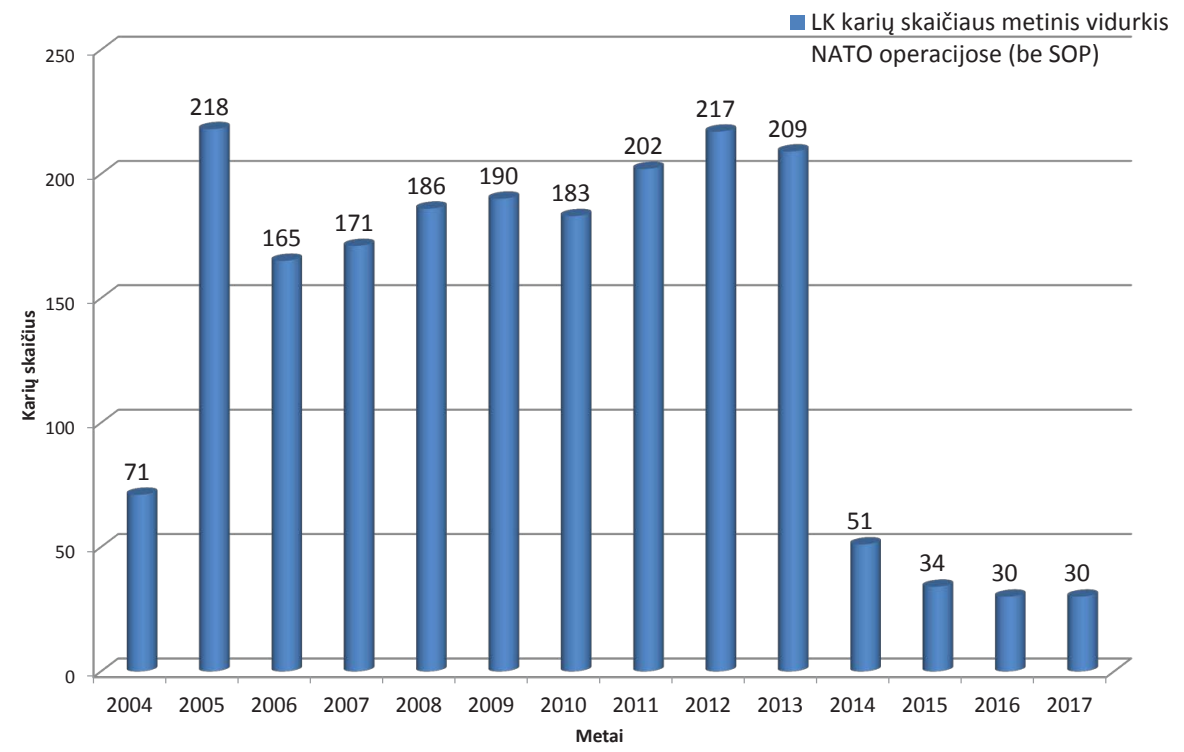

2 pav. Lietuvos kariụ skaičiaus NATO operacijose metinis vidurkis, be Specialiujų operacijų pajègu

\footnotetext{
${ }^{21}$ Ten pat, p. 71.

${ }^{22}$ Lietuvos Respublikos krašto apsaugos ministerija (2017), Lietuvos karių dalyvavimas tarptautinėse operacijose 2017 m. gruodžio mèn., http://kam.lt/lt/tarptautinis_bendradarbiavimas/tarptautines_operacijos.html, 2017-12-07 17.24 val.
} 


\subsubsection{Lietuvos indèlio i Europos Sajungos operacijas 2004-2017 m. apžvalga}

Lietuvos karių dalyvavimas Europos Sąjungos tarptautinėse operacijose ir mokymo misijose 2004-2017 m. didejo. I ES operaciją "Althea“ Bosnijoje ir Hercegovinoje nuo $2004 \mathrm{~m}$. iki $2010 \mathrm{~m}$. pabaigos buvo skiriami pavieniai štabo karininkai. Iš viso šioje operacijoje per 6 metus dalyvavo 12 LK karininkų ${ }^{23}$. ES karinejje jūrų operacijoje „Atalanta“, skirtoje kovai su ginkluotais plěšimais jūroje, Lietuva nuo $2011 \mathrm{~m}$. skiria vieną štabo karininką. Lietuvos indèlis ị ES operacijas pradeda didèti 2013 m., kai į ES karinę mokymo operaciją Malyje nuo kovo ménesio buvo skirti 2 Lietuvos kariai. Tų pačių metų rugpjūčio mėn. i ES operaciją „Atalanta“ papildomai dislokuota Autonominè laivų apsaugos grupè (toliau - ALAG), sudaryta iš $16 \mathrm{LK}$ karių, skirta saugoti humanitarines siuntas gabenantị Pasaulio maisto programos laivą, ir nacionalinis paramos elementas - 2 kariai. Bendras 20 LK karių indèlis ị operaciją "Atalanta" tapo didžiausiu Lietuvos indèliu ị Europos Sąungos operacijas ${ }^{24}$, o iš LK karių suformuotos ALAG ị ES operaciją „Atalanta“ taip pat skirtos 2015 m., 2016 m. ir $2017 \mathrm{~m}$.

2015 m. ES pradèjo vykdyti karinę jūrinę operaciją EUNAVFOR MED „Sophia“, siekdama užkirsti kelią nelegaliam žmonių gabenimui iš Šiaurès Afrikos $^{25}$. Nuo pat operacijos pradžios Lietuva skiria 1 karininką ị operacijos vadavietę Romoje, o nuo $2016 \mathrm{~m}$. papildomai skiriami 2 karininkai ị operacijos pajègų vadavietę, dislokuotą laive. $2017 \mathrm{~m}$. Lietuva padidino indèlị i x šią prioritetinę ES operaciją skirdama Laivų apžiūros grupę, sudarytą iš 12 LK karių. I Europos Sąjungos karinę mokymo operaciją Centrinès Afrikos Respublikoje (angl. EUTM RCA) Lietuva nuo 2017 m. balandžio mèn. skiria 1 štabo karininką $\mathfrak{i}$ operacijos vadavietę. Lietuvos karių skaičiaus ES operacijose metinis vidurkis pateiktas 3 pav.

\footnotetext{
${ }^{23}$ Lietuvos Respublikos krašto apsaugos ministerija (2014). „Taikos sargyboje: Lietuvos kariai tarptautinèse operacijose 1994-2014 m.“, p. 59.

${ }^{24}$ Ten pat, p. 79.

${ }^{25}$ Lietuvos kariuomenès Jungtinis štabas (2017), vykdomos tarptautinès operacijos, http://www.jungtinisstabas.lt/lt/vykdomos-to/eunavformed/, 2017-12-10 $15.28 \mathrm{val}$.
} 


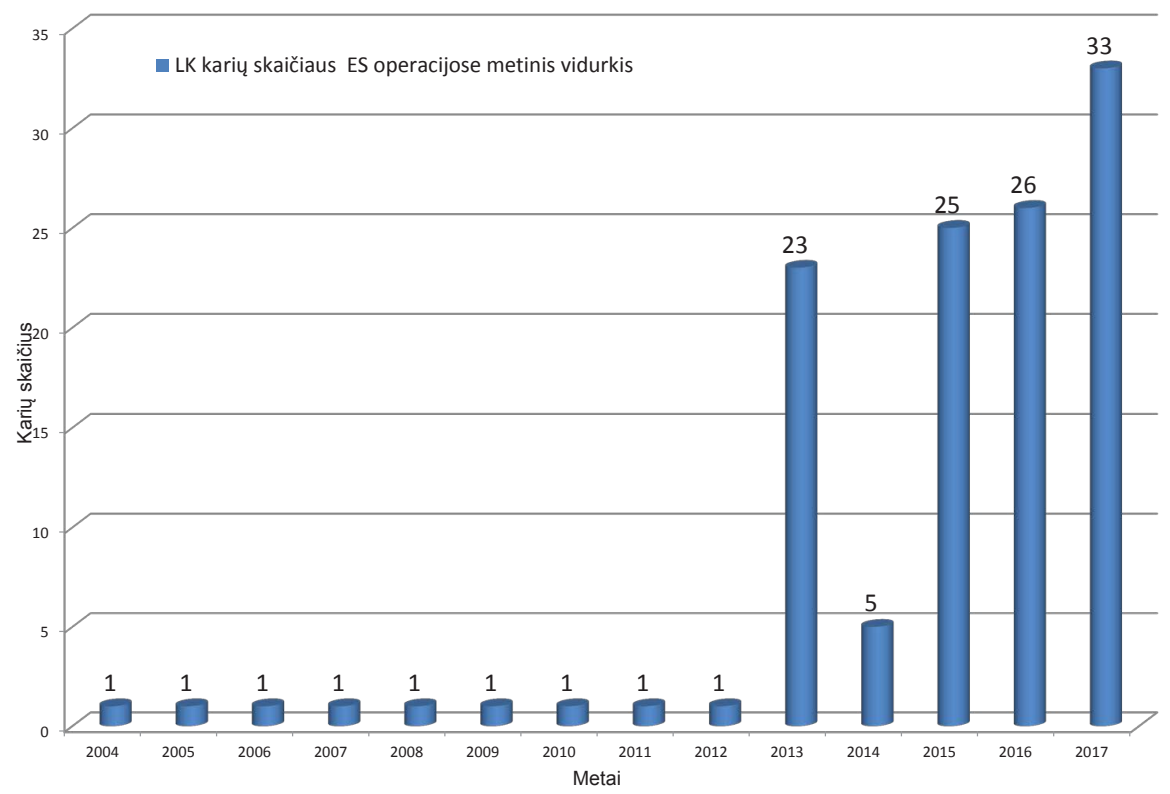

3 pav. Lietuvos karių skaičiaus ES operacijose metinis vidurkis

\subsubsection{Lietuvos indèlio i Jungtinių Tautų operacijas} 2004-2017 m. apžvalga

Aktyviai prisidedama prie Jungtinių Tautų (toliau - JT) taikos ir tarptautinio saugumo palaikymo, Lietuva nuo $1994 \mathrm{~m}$. dalyvauja JT vykdomose taikos palaikymo operacijose. Per minètą laikotarpi Lietuva dalyvavo daugiau nei 14 JT vykdytų tarptautinių operacijų ${ }^{26}$.

Pagal valstybių indèli kariais, kariniais ekspertais, štabo karininkais, policijos pareigūnais ị JT operacijas, šalys yra reitinguojamos. 2004-2017 m. Lietuvos indèlis kariais ir policijos pareigūnais i jT operacijas ir vieta JT reitinge pateikta 4 pav.

\footnotetext{
${ }^{26}$ Lietuvos Respublikos nuolatinè misija Jungtinėse Tautose (2017). Lietuvos prioritetai Jungtinėse Tautose. https://mission-un-ny.mfa.lt/missionny/lt/lietuva-jungtinese-tautose/lietuvos-prioritetai-jt, 2017-11-10 11.21 val.
} 


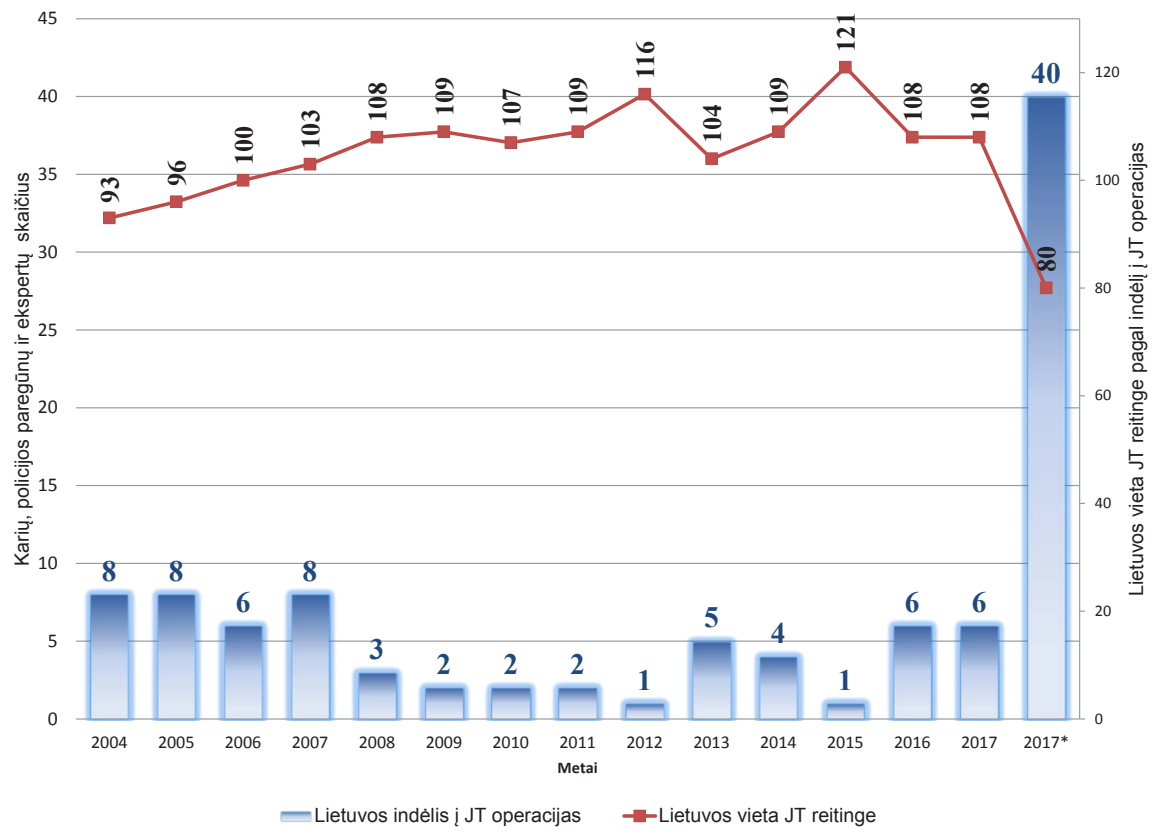

4 pav. Lietuvos kariụ ir policijos pareigūnų skaičiaus JT operacijose metinis vidurkis ir vieta JT reitinge pagal šalies indèli i JT operacijas personalu ${ }^{27}$

Lietuvos indèlis 2004-2017 m. ị JT operacijas svyravo nuo 1 iki 8 karių ir policijos pareigūnų. Minètu laikotarpiu didžiausia Lietuvos kontribucija ị JT operacijas buvo 2004, 2005, 2007 m., kai Lietuva skyre 8 karius ir policijos pareigūnus. Mažiausias Lietuvos indèlis i j JT operacijas buvo 2009-2012 m., kai JT operacijose dalyvavo 1-2 LK kariai ir policijos pareigūnai. Lietuvos vieta JT reitinge pagal skiriamo personalo skaičių dalyvauti JT operacijose iš 93 vietos $2004 \mathrm{~m}$. nukrito ị 108 vietą $2017 \mathrm{~m}$. rugpjūčio mèn.

Lietuvos indèli kariais ir policijos pareigūnais ị JT tarptautines operacijas objektyviau būtų galima ịvertinti palyginus jị su Šiaurès ir Baltijos šalių teikiamu indèliu. Lietuvos indèlio į JT operacijas palyginimas su Šiaurès ir Baltijos šalių indèliu pateiktas 5 pav.

\footnotetext{
${ }^{27}$ United Nations Peacekeeping (2017), Peacekeeping Operations, Resources, Data Troop and police contributors (2004-2017), https://peacekeeping.un.org/en/troop-and-police-contributors, 2017-11-28 18.55 val.
} 


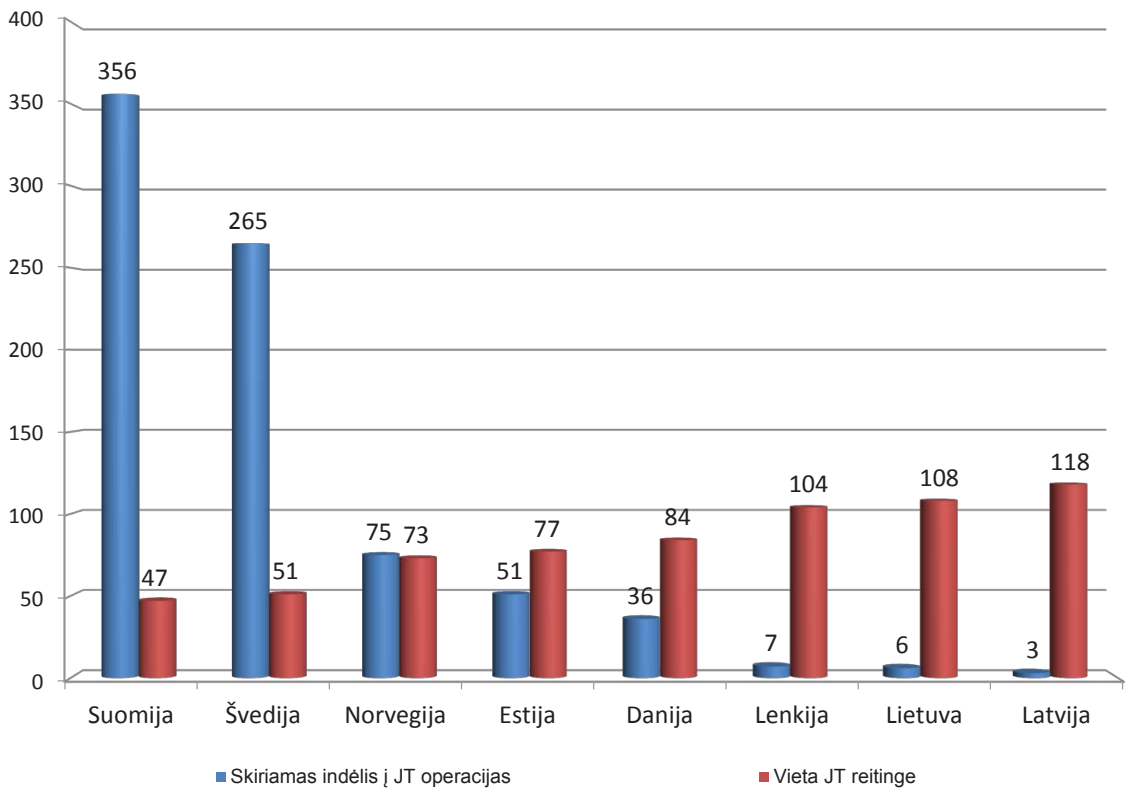

\section{5 pav. Lietuvos indėlis ir vieta JT reitinge pagal skiriamą indèlị personalu i JT operacijas ${ }^{28} 29$}

2017 m. spalio ménesi i JT situacijos stabilizavimo operaciją Malyje (angl. MINUSMA) išvyko iš Lietuvos kariuomenės karių suformuotas Pajėgụ apsaugos vienetas su Nacionalinès paramos elementu ${ }^{30}$. Lietuvos karių kontingentas šioje operacijoje padidejo nuo 5 iki 3931, o bendras šalies indèlis i JT operacijas išaugo iki 40 karių ir policijos pareigūnų. Lietuva pagal skiriamą tokio dydžio indèlị i JT operacijas $2017 \mathrm{~m}$. pabaigoje turètų pakilti į 80 vietą $^{32}$ tarp visų JT narių.

\footnotetext{
${ }^{28}$ Ten pat.

${ }^{29}$ Pastaba. 2017-12-30 JT duomenų bazèje informacija apie rekordiškai padidintą Lietuvos indèli ̣ j JT operacijas dar nebuvo atnaujinta. Faktinis Lietuvos indèlis 2017 m. - 39 kariai ir 1 policijos pareigūnas, Lietuvai turètų leisti pakilti JT reitinge ir atsidurti tarp Estijos ir Danijos pagal teikiamą indèli i jT operacijas Šiaurès ir Baltijos šalių kontekste.

${ }^{30}$ LR užsienio reikalų ministerija (2017). Spaudos pranešimas „Dar 34 Lietuvos kariai pradejjo tarnybą Malyje“ http://www.urm.lt/default/lt/naujienos/dar-34-lietuvos-kariai-pradejo-tarnyba-malyje,2017-11-02 17.24 val.

${ }^{31}$ Lietuvos Respublikos krašto apsaugos ministerija (2017), Lietuvos karių dalyvavimas tarptautinèse operacijose 2017 m. gruodžio mèn., http://kam.lt/lt/tarptautinis_bendradarbiavimas/tarptautines_operacijos.html, 2017-12-10 11.22 val.

${ }^{32}$ Pastaba. Atsižvelgiant ị prielaidą, kad kitų šalių teikiamas indèlis ị JT operacijas gerokai nesikeis.
} 


\subsubsection{7 m. NATO, ES, JT, sajungininkų vykdytos ir kitos tarptautinès operacijos}

2017 m. NATO vykde 3 tarptautines operacijas: operaciją „Tvirta parama“ (angl. „Resolute Support“) Afganistane, taikos palaikymo operaciją Kosove (angl. KFOR), „Jūrų saugotojo“ (angl. „Sea Guardian“) operaciją Viduržemio jūroje, kuriose dalyvavo apie 18000 karių. Be šių operacijų, NATO teikè paramą Afrikos Sąungai, Turkijai, vykdè oro policijos misijas sąungininkių prašymu. Lietuvos Respublikos krašto apsaugos ministerijos duomenimis ${ }^{33}$, Lietuva 2017 m. skyrè karinę paramą dviem NATO operacijoms: taikos palaikymo operacijai Kosove ir operacijai „Tvirta parama“ Afganistane ${ }^{34}$.

Europos Sąjunga 2017 m. iš viso vykdè 16 karinių ir civilinių operacijų ir misijų ${ }^{35}$ trijuose žemynuose (Europoje, Afrikoje, Azijoje) ${ }^{36}$, kuriose dalyvavo daugiau nei 4000 karių ir civilių. Iš minètų 16 operacijų, 6 buvo vykdomos remiantis kariniais pajėgumais. Lietuvos Respublikos krašto apsaugos ministerijos duomenimis ${ }^{37}, 2017$ m. gruodžio mèn. Lietuvos kariai dalyvavo keturiose iš šešių ES vykdomų karinių operacijų ar mokymo misijų: ES operacijoje „Sophia“ Viduržemio jūroje, ES kovos su piratavimu operacijoje „Atalanta“ Indijos vandenyne, ES karinèje mokymo misijoje Centrinès Afrikos Respublikoje ir ES karinejje mokymo misijoje Malyje.

Jungtinès Tautos $2017 \mathrm{~m}$. iš viso vykde 15 tarptautinių taikos palaikymo operacijų ${ }^{38}$, kuriose dalyvavo daugiau nei 110000 karių, policijos pareigūnų ir civilių. Lietuva $2017 \mathrm{~m}$. dalyvavo dviejose ${ }^{39}$ JT taikos palaikymo operacijose stabilizavimo operacijoje MINUSMA Malyje ir UNFICYP Kipre. 2017 m. gruodžio mèn. šiose taikos palaikymo operacijose dalyvavo 39 Lietuvos kariai ir 1 policijos pareigūnas.

\footnotetext{
${ }^{33}$ Lietuvos Respublikos krašto apsaugos ministerija (2017), Lietuvos karių dalyvavimas tarptautinėse operacijose $2017 \mathrm{~m}$. gruodžio mèn., http://kam.lt/lt/tarptautinis_bendradarbiavimas/tarptautines_operacijos. html, 2017-12-10 17.26 val.

34 Ten pat.

${ }^{35}$ European Union External Action Service (2017), Military and civilian missions and operations, https://eeas.europa.eu/headquarters/headquarters-homepage/area/security-and-defence_en, 2017-08-11 10.34 val.

${ }^{36}$ Ten pat.

${ }^{37}$ Lietuvos Respublikos krašto apsaugos ministerija (2017), Lietuvos karių dalyvavimas tarptautinėse operacijose $2017 \mathrm{~m}$. gruodžio mèn., http://kam.lt/lt/tarptautinis_bendradarbiavimas/tarptautines_operacijos. html, 2017-12-10 11.24 val.

${ }^{38}$ United Nations Peacekeeping (2017), Peacekeeping Operations, http://www.un.org/en/peacekeeping/ resources/statistics/factsheet.shtml, 2017-12-28 11.55 val.

${ }^{39}$ Ten pat.
} 


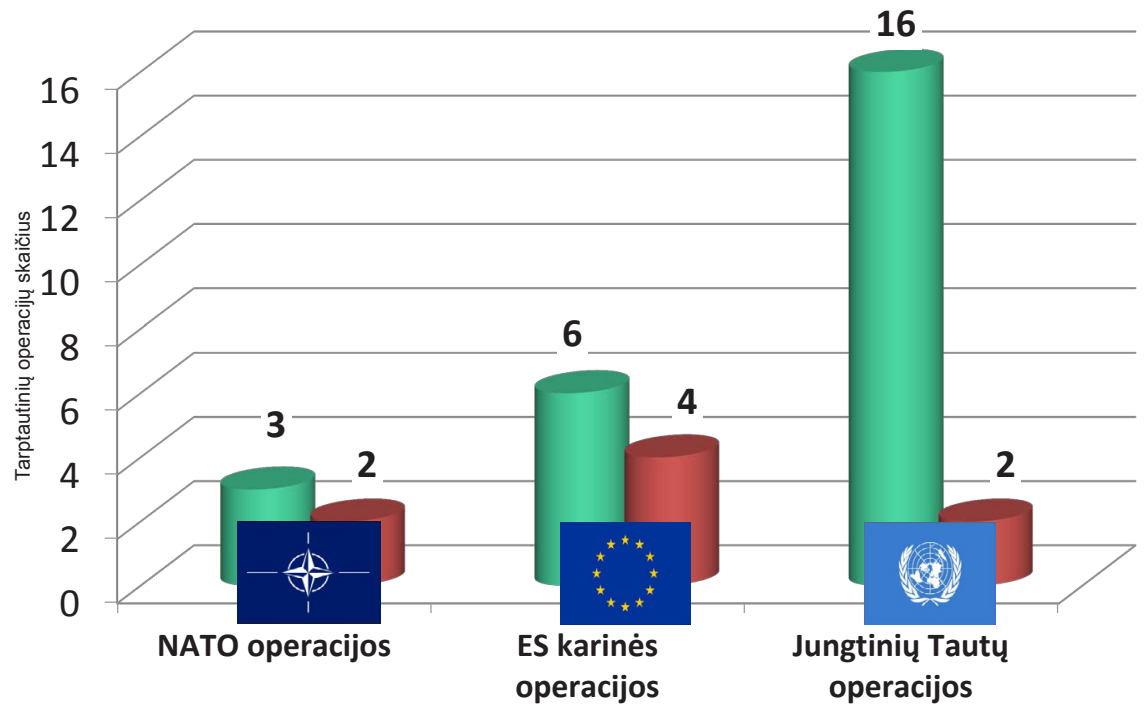

— 2017 m. vykusių tarptautinių operacijų skaičius @ Operacijų skaičius, kuriose dalyvavo Lietuvos kariai

\section{6 pav. Lietuvos karių dalyvavimas NATO, ES, JT tarptautinèse operacijose $2017 \mathrm{~m}$.}

Dalyvaudama "Globalios koalicijos kovoje prieš Islamo valstybę“ veikloje, Lietuva 2017 m. skyrè karinį indèli - 6 karinius instruktorius operacijai „Igimtas ryžtas" Irake ${ }^{40}$.

Lietuva nuo $2017 \mathrm{~m}$. liepos $1 \mathrm{~d}$. taip pat skiria karinę paramą operacijai mokymo tikslais Ukrainoje. Lietuvos Respublikos krašto apsaugos ministerijos duomenimis ${ }^{41}$, šioje operacijoje mokymo tikslais dalyvauja apie 40 Lietuvos kariuomenès karių. Lietuvos karių kontingento dydis tarptautinėse operacijose $2017 \mathrm{~m}$. pateiktas 2 lentelèje.

\footnotetext{
${ }^{40}$ The Global Coalition (2017), Partners, Lithuania, http://theglobalcoalition.org/en/partners/lithuania/,2017-09-10 19.23 val.

${ }^{41}$ Lietuvos Respublikos krašto apsaugos ministerija (2017), Lietuvos karių dalyvavimas tarptautinėse operacijose 2017 m. gruodžio mèn., http://kam.lt/lt/tarptautinis_bendradarbiavimas/tarptautines_operacijos. html, 2017-12-01 12.26 val.
} 
2 lentelè. Lietuvos karių kontingento dydis tarptautinèse operacijose $2017 \mathrm{~m}^{42}$

\begin{tabular}{|c|c|c|}
\hline Operacija & $\begin{array}{c}\text { Karių } \\
\text { skaičius }\end{array}$ & Iš viso \\
\hline NATO KFOR & 1 & \multirow{2}{*}{$\begin{array}{c}\text { NATO operacijose daly- } \\
\text { vavo } 30 \text { karių }\end{array}$} \\
\hline NATO operacija „Tvirta parama“ Afganistane & 29 & \\
\hline ES operacija „Sophia“ & 15 & \multirow{4}{*}{$\begin{array}{c}\text { ES operacijose ir karinèse } \\
\text { mokymo misijose dalyvavo } \\
33 \text { kariai }\end{array}$} \\
\hline ES operacija „Atalanta“ & 15 & \\
\hline ES mokymo misija Centrinès Afrikos Respublikoje & 1 & \\
\hline ES mokymo misija Malyje & 2 & \\
\hline Operacija „Igimtas ryžtas“ Irake & 6 & $\begin{array}{l}\text { JAV vadovaujamoje ope- } \\
\text { racijoje dalyvavo } 6 \text { kariai }\end{array}$ \\
\hline JT stabilizavimo operacija MINUSMA Malyje & 39 & $\begin{array}{c}\text { JT operacijose dalyvavo } \\
39 \text { kariai }\end{array}$ \\
\hline Operacija mokymo tikslais Ukrainoje & apie 40 & Dalyvavo apie 40 kariu \\
\hline
\end{tabular}

Lietuvos karinio indèlio $2017 \mathrm{~m}$. ̣̇ NATO, ES, JT ir kitas tarptautines operacijas kariais procentinè išraiška, pagal 2 lentelèje esančius duomenis, pateikta 7 pav.

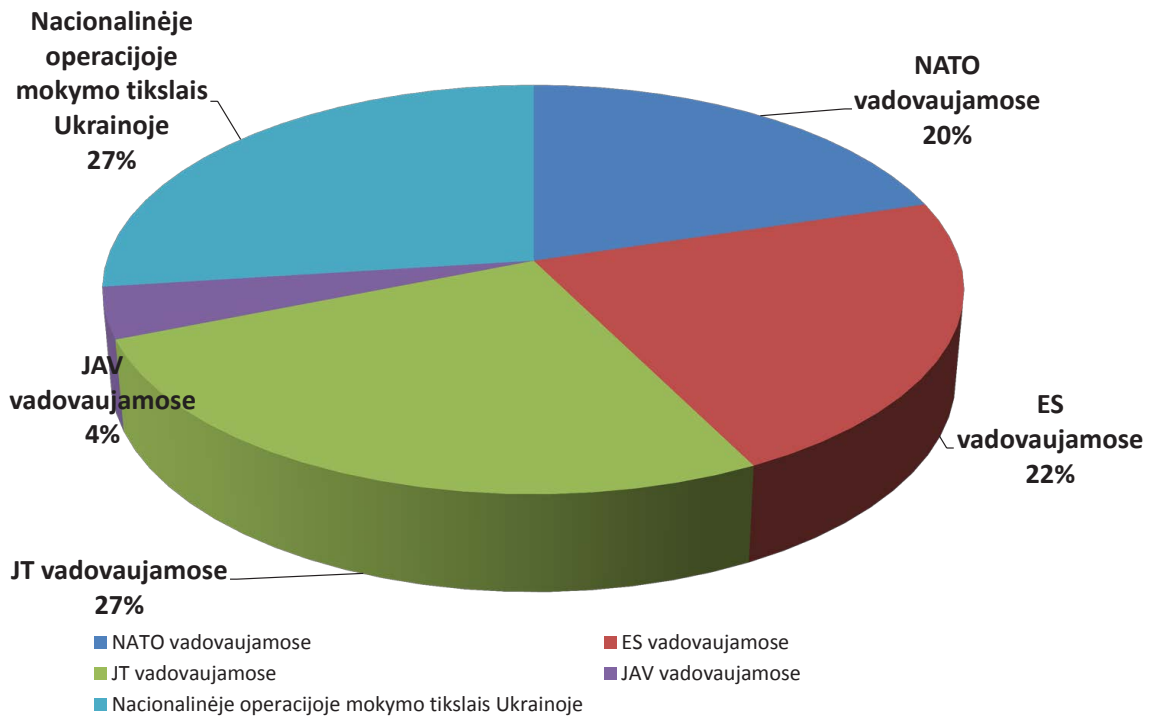

\section{7 pav. 2017 m. Lietuvos karių, dalyvaujančių NATO, ES, JT tarptautinèse operacijose, dalis proc.}

\footnotetext{
${ }^{42}$ Lietuvos Respublikos krašto apsaugos ministerija (2017), Lietuvos karių dalyvavimas tarptautinėse operacijose $2017 \mathrm{~m}$.
} 
Atsižvelgiant ị pateiktą informaciją, darytina išvada, kad Lietuva nuo 2014 m. sumažinusi karinị indèlị ị NATO vykdomas operacijas pradejo jị didinti ES, JT ir kitose partnerių vykdomose tarptautinèse operacijose. Remiantis Lietuvos karių dalyvavimo tarptautinèse operacijose $2017 \mathrm{~m}$. duomenimis (žr. 7 pav.), pastebima tendencija, kad Lietuva skiria subalansuotą karinę paramą NATO, ES ir JT vykdomoms tarptautinèms operacijoms.

\section{LR krašto apsaugos sistemos turimi ištekliai dalyvavimui tarptautinèse operacijose}

Valstybės karinių pajėgumų arba kariuomenės efektyvumo svarstymas pirmiausiai turètų prasidèti nuo išteklių - finansinių, žmogiškųjų, fizinių ir technologiniu - ịvertinimo, kuriuos karinèms organizacijoms suteikia šalies nacionalinė

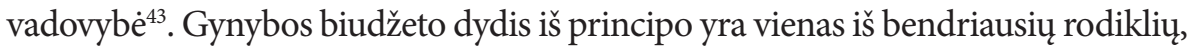
parodančiu politinès valdžios skiriamus išteklius kariuomenei. Tuo pačiu šis dydis padeda parodyti santykinę kariuomenès ar karinės galios svarbą, lyginant su kitomis valstybės institucijomis, ir perteikia bendrą kariuomenès struktūros dydžio supratimą absoliučiais skaičiais ${ }^{44}$. NATO šalių ịsipareigojimai Aljansui bei jų požiūris ị gynybą taip pat vertinami pagal šalies skiriamus asignavimus gynybai: faktinèmis išlaidomis ir procentine išraiška nuo BVP. 2006 m. Rygoje $e^{45}$ vykusio NATO viršūnių susitikimo metu šalys narès sutare siekti sustabdyti gynybai skiriamų išlaidų mažinimą ir stengtis nuosekliai didinti realų finansavimą gynybai. NATO viršūnių susitikime Velse ${ }^{46} 2014$ m. raštiškai ịtvirtinta nuostata dèl 2 proc. nuo BVP skyrimo gynybai. Susitikimo metu susitarta per artimiausią dešimtmetị siekti visoms Aljanso narèms didinti realų finansavimą gynybai, skiriant ne mažiau kaip 2 proc. nuo BVP, o investicijos ị ginkluotės ir ịrangos atnaujinimą turètų sudaryti ne mažiau kaip 20 proc. gynybos biudžeto. Lietuvos dalyvavimas tarptautinėse operacijose taip pat priklauso nuo finansinių išteklių - LR krašto apsaugos sistemos (toliau - LR KAS) finansavimo, nes faktiškai skiriamas finansavimas LR KAS tiesiogiai daro ittaką galimybei aprūpinti, parengti, perdislokuoti ir išlaikyti LK karinius vienetus ir karius tarptautinès operacijos rajone.

\footnotetext{
${ }^{43}$ Ashley J. Tellis, Janice Bially, Christopher Layne, Melissa McPherson (2001), Measuring National Power in the Postindustrial Age, p. 136 https://www.rand.org/pubs/monograph_reports/MR1110.html, 2017-06-30 19.45 val.

${ }^{44}$ Ten pat, p. 136

${ }^{45}$ NATO, Riga Summit Declaration (2006), http://www.nato.int/docu/pr/2006/p06-150e.htm, 2017-08-10 21.44 val.

${ }^{46}$ NATO, Wales Summit Declaration (2014), http://www.nato.int/cps/en/natohq/official_texts_112964.htm, 2017-08-10 22.11 val.
} 
Karinio personalo skaičius ir jo kokybė yra antroji išteklių sudedamoji dalis, leidžianti suvokti šalies nacionalinę galią̧ ${ }^{47}$. Akivaizdu, kad kariuomenès dydis, pirmiausia, yra svarbus kaip pirminis karinès galios indeksas, antra, kad kovineje aplinkoje kiekybė vis dar daro ịtaką ir kokybei ${ }^{48}$. Pakankamas skaičius gerai parengto ir motyvuoto personalo, skirto užtikrinti LR KAS keliamų uždavinių vykdymą, taip pat sudaro prielaidas sèkmingam šalies dalyvavimui tarptautinèse operacijose.

Apibendrinant galima teigti, kad be politinès valios - LR Seimo nutarimų, vienu iš esminių veiksnių, lemiančių Lietuvos karių ir civilių krašto KAS tarnautojų dalyvavimą tarptautinèse operacijose, gali būti išskiriami LR KAS turimi ištekliai. Skiriant karius ir civilius KAS tarnautojus ị tarptautines operacijas, būtų galima išteklius išskirti ị 2 pagrindines dalis: krašto apsaugos sistemai skiriamus asignavimus ir žmogiškuosius išteklius (personalą). Fizinių ir technologinių išteklių îtaka LK karių dalyvavimui tarptautinėse operacijose neanalizuojama dèl viešai prieinamos informacijos trūkumo.

\subsection{LR krašto apsaugos sistemai skirti asignavimai}

Informacija apie Lietuvos skirtas išlaidas gynybai 2004-2017 m., remiantis Pasaulio banko duomenimis ${ }^{49}$, pateikta 8 pav. Lietuvos skirtas finansavimas gynybai pagal procentinę dalị nuo šalies BVP 2004-2013 m. nuosekliai mažèjo: 2004 m. - 1,2 proc., 2013 m. - 0,76 proc. BVP. Išlaidų gynybai didinimas pagal BVP procentinę išraišką Lietuvoje fiksuotas tik nuo 2014 m., o asignavimai gynybai $2017 \mathrm{~m}$. jau siekia 1,78 proc. BVP. Planuojama, kad Lietuva igyvendins NATO rekomendacijas ir užtikrins išlaidas gynybai ne mažiau kaip 2 proc. nuo BVP $2018 \mathrm{~m}^{50}$.

\footnotetext{
${ }^{47}$ Ashley J. Tellis, Janice Bially, Christopher Layne, Melissa McPherson (41 išnaša), p. 138, https://www. rand.org/pubs/monograph_reports/MR1110.html, 2017-06-30 19.55 val.

${ }^{48}$ Ten pat, p. 138.

${ }^{49}$ The World Bank (2017), Data Bank, World Development Indicators, Military expenditures, Lithuania, ,http://databank.worldbank.org/data/reports.aspx? source=2\&series=MS.MIL.XPND.CN\&country=LTU 2017-07-10 18.22 val.

${ }^{50}$ 2017-01-17 d. LR Seimo nutarimas Nr. XIII-202 „Dèl Lietuvos Respublikos Seimo 2002 m. gegužès 28 d. nutarimo Nr. IX-907 „Dèl Nacionalinio saugumo strategijos patvirtinimo“ pakeitimo“.
} 


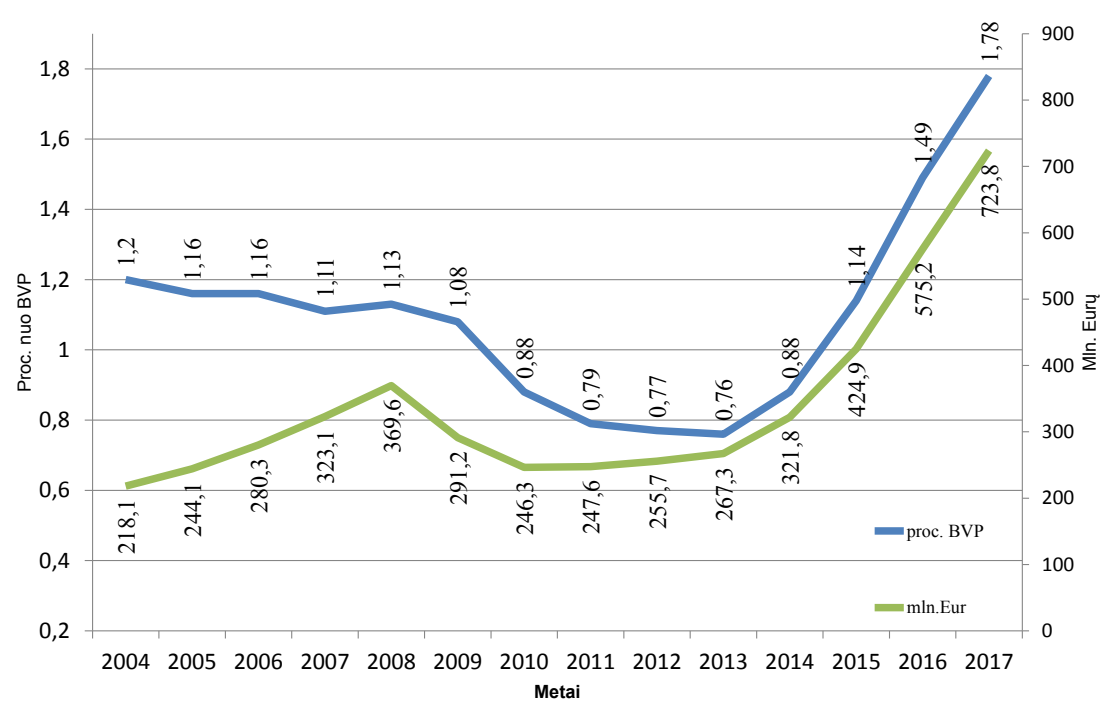

8 pav. LR krašto apsaugos sistemai skirtas finansavimas ${ }^{51}$

Lietuvos skiriamas finansavimas KAS 2004-2017 m. labai kito. Nors faktiškai asignavimai KAS 2004-2008 m. nuosekliai didèjo apie $40 \mathrm{mln}$. Eur. kasmet, $2009 \mathrm{~m}$. fiksuotas beveik $80 \mathrm{mln}$. Eur mažesnis finansavimas, o 2010 m. jis beveik grị̌o ị $2005 \mathrm{~m}$. lygị ir sudare tik kiek daugiau nei $246 \mathrm{mln}$. Eur. Ryškus faktinių išlaidų gynybai didinimas, kasmet beveik po $150 \mathrm{mln}$. Eur, fiksuojamas nuo $2014 \mathrm{~m}$. Taip pat pažymètina, kad finansavimas KAS $2017 \mathrm{~m}$., lyginant su 2010 m., išaugo maždaug 3 kartus ir beveik pasiekè $724 \mathrm{mln}$. Eur.

Lietuvos gynybos biudžeto didinimas $2014 \mathrm{~m}$. 20,4 proc., $2015 \mathrm{~m}$. - 32,0 proc. ir 2016 m. - 35,2 proc. leido išlaikyti vieną sparčiausių krašto apsaugai skiriamų asignavimų augimo tempų tarp visų NATO valstybių ${ }^{52}$. Paskutiniųjų metų spartus Lietuvos gynybos išlaidų didinimas 2016 m. pakele Lietuvą iš priešpaskutinès vietos $2013 \mathrm{~m} \cdot \cdot^{53}$ i 9 -ajją vietą tarp visų NATO šalių pagal išlaidas gynybai nuo BVP ${ }^{54}$.

\footnotetext{
${ }^{51}$ The World Bank (2017), Data Bank, World Development Indicators, Military expenditures, Lithuania, ,http://databank.worldbank.org/data/reports.aspx?source=2\&series=MS.MIL.XPND.CN\&country=LTU 2017-07-10 18.22 val.

${ }^{52}$ LR krašto apsaugos ministerija (2017), Krašto apsaugos ministerijos $2016 \mathrm{~m}$. veiklos ataskaita. 1 priedas. Gynybos finansavimas, http://kam.lt/download/57846/12-01-344_2016\%20m.\%20veiklos\%20ataskaita.pdf, 2017-09-20.

${ }^{53}$ NATO (2014), Financial and Economic Data Relating to NATO Defence,(PR/CP (2014)028). http:// www.nato.int/nato_static_fl2014/assets/pdf/pdf_topics/20140224_140224-PR2014-028-Defence-exp.pdf ${ }^{54}$ NATO (2017), The Secretary General's Annual Report 2016, p. 110, http://www.nato.int/nato_static_ fl2014/assets/pdf/pdf_2017_03/20170313_SG_AnnualReport_2016_en.pdf, 2017-09-22.
} 


\subsection{Krašto apsaugos sistemos žmogiškieji ištekliai}

Lietuva $\mathfrak{i}$ tarptautines operacijas skiria profesinès karo tarnybos (toliau PKT) karius, karius savanorius bei civilius KAS tarnautojus ${ }^{55}$. Šios trys KAS personalo kategorijos turi esminę reikšmę vertinant KAS žmogiškuosius išteklius. KAS žmogiškujų išteklių pokytis 2004-2017 m. pavaizduotas 9 pav.

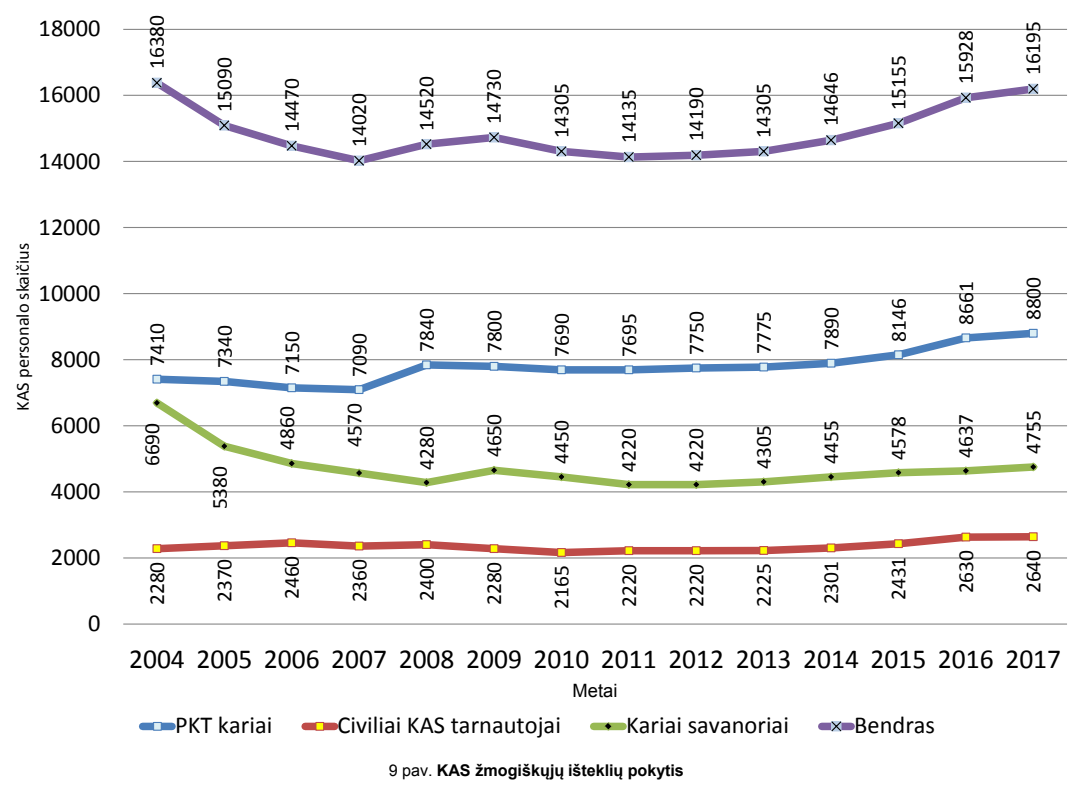

9 pav. KAS žmogiškujjų ištekliụ pokytis ${ }^{56}$

2004-2017 m. PKT karių skaičius padidèjo nuo 7410 iki 8 800, arba 18,8 proc. Nuo $2004 \mathrm{~m}$. karių savanorių skaičius nuosekliai mažèjo iki $2012 \mathrm{~m}$. (nuo 6690 iki 4 200). Nepaisant to, kad nuo 2013 m. karių savanorių skaičius pradejo nuosekliai didèti ir $2017 \mathrm{~m}$. pasiekè 4755 , bendras karių savanorių skaičius, lyginant su 2004 m., sumažèjo 29,1 proc. Civilių KAS tarnautojų skaičius 2004-2017 m. padidèjo nuo 2280 iki 2 640, arba 15,8 proc. Mažiausias KAS personalo skaičius buvo 2007 m. - 14 020, o 2006-2014 m. jis buvo vidutiniškai 11,28 proc. mažesnis nei $2017 \mathrm{~m}$.

\footnotetext{
${ }^{55}$ Lietuvos Respublikos Vyriausybès 2004 m. kovo 17 d. nutarimas Nr. 287 „Dèl Lietuvos karių ir civilių krašto apsaugos sistemos tarnautojų tarnybos tarptautinių operacijų kariniuose vienetuose, tarptautinėse operacijose ir rengimosi joms sąlygų patvirtinimo“, II dalis, 4 punktas. https://www.e-tar.lt/portal/lt/lega1Act/TAR.412D8A47D01B, 2017-10-02.

${ }^{56}$ LR krašto apsaugos ministerija (2017), KAS personalo skaičius, http://kam.lt/lt/personalo_politika_512/ skaiciai_ir_faktai_537.html, 2017-08-26 19.28 val.
} 
Vertinant bendrą KAS žmogiškujų išteklių pokytị nuo 2004 m. (16 380 asmenų) iki 2017 m. (16 195 asmenų), galima teigti, kad žmogiškųjų išteklių skaičius faktiškai nepakito (sumažèjo tik 1,1 proc.), tačiau pažymėtina, kad karius savanorius pakeite PKT kariai.

\subsection{Politinės valios ir krašto apsaugos sistemos išteklių palyginimas}

Vertindami LR Seimo nutarimais leisto dalyvauti tarptautinèse operacijose karių ir civilių KAS tarnautojų didžiausią skaičių su LR KAS turimais žmogiškaisiais ištekliais, galime gauti rodikli - procentinę išraišką, parodančią, kokią LR KAS žmogiškųjų išteklių dalị buvo leista siųsti dalyvauti ị tarptautines operacijas (žr. 3 lentelę).

3 lentelè. PKT karių ir civilių KAS tarnautojų dalyvavimo tarptautinèse operacijose rodikliai

\begin{tabular}{|c|c|c|c|c|c|}
\hline Metai & $\begin{array}{c}\text { KAS } \\
\text { žmogiškieji } \\
\text { ištekliai }\end{array}$ & $\begin{array}{l}\text { PKT ir karių } \\
\text { savanorių } \\
\text { skaičius }\end{array}$ & $\begin{array}{l}\text { Didžiausias } \\
\text { leidžiamas dalyvauti } \\
\text { TO kariụ civiliụ KAS } \\
\text { tarnautoju skaičius } \\
\text { (LR Seimo nutarimu) }\end{array}$ & $\begin{array}{l}\text { Leidžiamas da- } \\
\text { lyvauti TO KAS } \\
\text { žmogiškujų } \\
\text { išteklių proc. }\end{array}$ & $\begin{array}{c}\text { Leidžiamas } \\
\text { dalyvauti TO } \\
\text { PKT karių ir } \\
\text { karių savanorių } \\
\text { proc. }\end{array}$ \\
\hline 2004 & 16380 & 14100 & 330 & 2,01 & 2,34 \\
\hline 2005 & 15090 & 12720 & 350 & 2,32 & 2,75 \\
\hline 2006 & 14470 & 12010 & 420 & 2,90 & 3,50 \\
\hline 2007 & 14020 & 11660 & 420 & 3,00 & 3,60 \\
\hline 2008 & 14520 & 12120 & 420 & 2,89 & 3,47 \\
\hline 2009 & 14730 & 12450 & 420 & 2,85 & 3,37 \\
\hline 2010 & 14305 & 12140 & 420 & 2,94 & 3,46 \\
\hline 2011 & 14135 & 11915 & 420 & 2,97 & 3,52 \\
\hline 2012 & 14190 & 11970 & 355 & 2,50 & 2,97 \\
\hline 2013 & 14305 & 12080 & 265 & 1,85 & 2,19 \\
\hline 2014 & 14646 & 12345 & 275 & 1,88 & 2,23 \\
\hline 2015 & 15155 & 12724 & 265 & 1,75 & 2,08 \\
\hline 2016 & 15928 & 13298 & 175 & 1,10 & 1,32 \\
\hline 2017 & 16195 & 13555 & 235 & 1,45 & 1,73 \\
\hline
\end{tabular}

Atsižvelgiant $\mathfrak{i}$ tai, kad civilių KAS tarnautojų, faktiškai siųstų i tarptautines operacijas, skaičius 2004-2017 m. yra santykinai mažas, palyginus su PKT karių ir karių savanorių skaičiumi, 3 lentelèje taip pat pateikta leidžiamo PKT karių ir savanorių dalyvauti tarptautinèse operacijose skaičiaus procen- 
tinè išraiška. Pažymètina, kad didžiausią KAS žmogiškụjų išteklių dali buvo leista siųsti ị tarptautines operacijas $2007 \mathrm{~m}$. - 3,00 proc. (karių - 3,60 proc.), 2011 m. - 2,97 proc. (karių - 3,52 proc.), 2010 m. - 2,94 proc. (karių - 3,46 proc.), o mažiausią $2016 \mathrm{~m}$. - 1,10 proc. (karių - 1,32 proc.).

Siekiant tiksliau ịvertinti LR KAS turètus finansinius išteklius, jų pokyti ir santykị su KAS žmogiškaisiais ištekliais, galima apskaičiuoti konkrečiais metais vienam PKT kariui, kariui savanoriui ar civiliui KAS tarnautojui tenkantị santykinị KAS metinio finansavimo rodiklį (4 lentelè). Šis rodiklis parodo, kiek LR KAS finansavimui skirtų lěšų eurais santykinai teko LR KAS vienam PKT kariui, kariui savanoriui ar civiliui KAS tarnautojui.

4 lentelè. Vienam PKT kariui, kariui savanoriui ar civiliui KAS tarnautojui tenkantis santykinis KAS metinio finansavimo rodiklis

\begin{tabular}{|c|c|c|c|c|c|}
\hline Metai & $\begin{array}{c}\text { KAS fi- } \\
\text { nansavimas, } \\
\text { mIn. Eur }\end{array}$ & $\begin{array}{c}\text { KAS } \\
\text { żmogiškieji } \\
\text { ištekliai }\end{array}$ & $\begin{array}{c}\text { PKT kariu } \\
\text { ir kariu } \\
\text { savanoriụ } \\
\text { skaičius }\end{array}$ & $\begin{array}{c}\text { Vienam PKT kariui, } \\
\text { kariui savanoriui ar } \\
\text { civiliui KAS tarnautojui } \\
\text { tenkantis santykinis KAS } \\
\text { metinis finansavimas, } \\
\text { Eur }\end{array}$ & $\begin{array}{c}\text { Vienam PKT } \\
\text { kariui, kariui } \\
\text { savanoriui tenkan- } \\
\text { tis santykinis } \\
\text { KAS metinis } \\
\text { finansavimas, Eur }\end{array}$ \\
\hline 2004 & 218,1 & 16380 & 14100 & 13315,02 & 15468,09 \\
\hline 2005 & 244,1 & 15090 & 12720 & 16176,28 & 19190,25 \\
\hline 2006 & 280,3 & 14470 & 12010 & 19371,11 & 23338,88 \\
\hline 2007 & 323,1 & 14020 & 11660 & 23045,65 & 27710,12 \\
\hline 2008 & 369,6 & 14520 & 12120 & 25454,55 & 30495,05 \\
\hline 2009 & 291,2 & 14730 & 12450 & 19769,18 & 23389,56 \\
\hline 2010 & 246,3 & 14305 & 12140 & 17217,76 & 20288,30 \\
\hline 2011 & 247,6 & 14135 & 11915 & 17516,80 & 20780,53 \\
\hline 2012 & 255,7 & 14190 & 11970 & 18019,73 & 21361,74 \\
\hline 2013 & 267,3 & 14305 & 12080 & 18685,77 & 22127,48 \\
\hline 2014 & 321,8 & 14646 & 12345 & 21971,87 & 26067,23 \\
\hline 2015 & 424,9 & 15155 & 12724 & 28036,95 & 33393,59 \\
\hline 2016 & 575,2 & 15928 & 13298 & 36112,51 & 43254,62 \\
\hline 2017 & 723,8 & 16195 & 13555 & 44692,81 & 53397,27 \\
\hline
\end{tabular}

Atsižvelgiant ị šią pateiktą informaciją, darytina išvada, kad šis rodiklis buvo mažiausias $2004 \mathrm{~m}$. (13 315 Eur), $2005 \mathrm{~m}$. (16 176 Eur), $2010 \mathrm{~m}$. (17 217 Eur) ir 2011 m. (17 516 Eur), o didžiausias 2016 m. (36 112 Eur) ir 2017 m. (44 692).

Politinès valios - LR Seimo nutarimais įtvirtintų sprendimų dèl LK karinių vienetų, karių dalyvavimo tarptautinèse operacijose 2004-2017 m. ir KAS turimų išteklių palyginimas pateiktas 10 pav. 


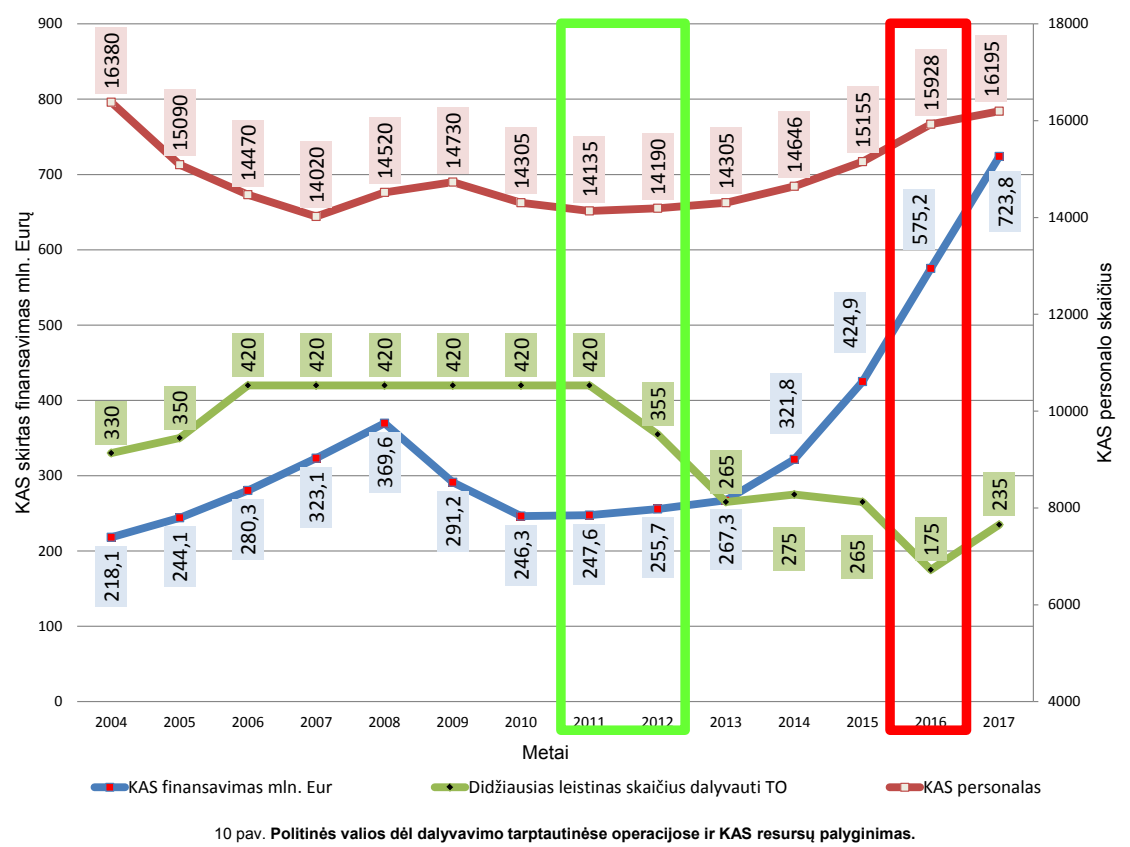

10 pav. Politinès valios dèl dalyvavimo tarptautinèse operacijose ir KAS turimų ištekliụ palyginimas

Pažymètina, kad 2010 m. ir 2011 m. LR Seimas buvo nustatęs didžiausią leidžiamą karių ir civilių KAS tarnautojų skaičių dalyvauti tarptautinėse operacijose, tačiau KAS tuo metu turèti finansiniai ir žmogiškieji ištekliai buvo mažiausi. Tuo tarpu santykinai didžiausi LR KAS turèti ištekliai, bet mažiausias karių, galinčių dalyvauti tarptautinėse operacijose, skaičius, nustatytas LR Seimo nutarimu, fiksuotas 2016 m. Pažymètina, kad LR Seimui, krizès laikotarpiu priimant sprendimą dèl karių dalyvavimo tarptautinèse operacijose, lemiamos ittakos turèjo ne tik KAS turimi ištekliai. Minètu laikotarpiu, tikètina, sąjungininkų pritraukimas labiausiai buvo suvokiamas per Lietuvos indèlio ị tarptautines operacijas skyrimą, todèl didžioji KAS išteklių dalis buvo skirta būtent tam.

\section{Vietoje išvadų: Lietuvos dalyvavimo tarptautinèse operacijose galimi scenarijai}

2004-2017 m. tarptautinèse operacijose dalyvavo kariai iš visų Lietuvos kariuomenès pajègų rūšių, įskaitant ir Krašto apsaugos savanorių pajègas. Tai rodo aukštą LK pajègų panaudojamumo, karių pasirengimo ir profesionalumo 
lygì, taip pat LK gebejjimą prisitaikyti prie jai keliamų reikalavimų ir skirti karinę paramą tarptautinėms operacijoms siekiant užtikrinti tarptautinị saugumą ir stabilumą. Lietuva didžiausią paramą iki 2013 m. skyrè NATO operacijoms, o prioritetinis regionas ilgą laiką buvo Afganistanas. Nuo 2013 m. išryškejja nauja tendencija - didèja LK karių indèlis ị ES vykdomas operacijas, $2017 \mathrm{~m}$. padidinta parama JT operacijoms ir pradèta vykdyti nacionalinė operacija Ukrainoje jos ginkluotųjų pajègų mokymo tikslais. Dèl šios priežasties 2017 m. matomas proporcingas LK karių dalyvavimas NATO, ES, JT ir kitose sąjungininkų vykdomose operacijose, taip pat išryškèja šalies indèlis ị nacionalinę operaciją Ukrainoje. Labai tiketina, kad proporcingas Lietuvos karinis indèlis ¿ NATO, ES ir JT vykdomas tarptautines operacijas išliks ir artimiausioje ateityje, o LK kariai greičiausiai prisijungs prie JAV, Vokietijos, Baltijos ir Šiaurès šalių formuojamų ar tarptautinèse operacijose dalyvaujančiu kontingentų.

Lietuvos karių indèlis $\mathfrak{i}$ tarptautines operacijas minètu laikotarpiu didejja ne tik karių skaičiumi, kai nuo skyrimo pavienių štabo karininkų ar instruktorių palaipsniui pereinama prie vienetų (Provincijos atkūrimo grupès, Pajègų apsaugos vieneto) ar grupių (instruktorių, laivų apžiūros, autonominès laivų apsaugos), bet ir kokybe. Specialiųjų operacijų pajęgų, Perdislokuojamo ryšių ir informacinių sistemų modulio, aukštos kvalifikacijos specialistų dislokavimas ị operacijų rajonus, Lietuvos karininkų skyrimas ị svarbias pozicijas operacijų štabuose ir vadavietèse rodo Lietuvos kariuomenès kokybini pokyti, dalyvaujant tarptautinèse operacijose. Vystant Lietuvos kariuomenès kovinius, kovinès paramos ar kitus nišinius pajègumus, ateityje jų dalyvavimo poreikis tarptautinèse operacijose nemažès, o tam tikrais atvejais didès. Dèl šios priežasties Lietuva ateityje turès galimybę svarstyti ir rinktis, kokią paramą tarptautinėms operacijoms pagal sąjungininkų išreikštą poreikị skirti: a) pavienius karius, štabo karininkus, mažas instruktorių ir tam tikrų specialybių karių grupes (ryšininkus, CIMIC specialistus ir pan.); b) dislokuoti ị operacijos rajoną kovinius, kovinès paramos vienetus, galbūt net bataliono dydžio, kur jie galètų igyti realios kovinès patirties, kuri būtų ypač vertinga ruošiantis valstybės ginkluotai gynybai.

Faktinis Lietuvos dalyvavimas tarptautinèse operacijose ir karių indèlis i jas priklausys nuo saugumo situacijos, NATO, Europos Sąungos, sąjungininkų vykdomų tarptautinių operacijų, strateginių partnerių išreikšto poreikio ir Lietuvos galimybių ${ }^{57}$. Tarptautinè saugumo situacija tiesiogiai darys ịtaką gali-

\footnotetext{
${ }^{57}$ LR krašto apsaugos ministerija (2017), Tarptautinis bendradarbiavimas, Tarptautinès operacijos, http://kam.lt/lt/tarptautinis_bendradarbiavimas/tarptautines_operacijos.html, 2017-11-03 19.33 val. https://www.delfi.lt/news/daily/lithuania/seimas-apsisprende-del-lietuvos-kariu-dalyvavimo-tarptautinese-operacijose. $\mathrm{d}$ ?id $=76032645$.
} 
mam Lietuvos dalyvavimui tarptautinèse operacijose. Tikètina, kad pasaulyje vykstančių tarptautinių operacijų, kuriose galètų dalyvauti Lietuva, skaičius ateityje drastiškai nesikeis. Lietuvai ir toliau išliks galimybe rinktis iš maždaug šešiolikos Europos Sąjungos vykdomų operacijų ir misijų, tokio pat skaičiaus Jungtinių Tautų operacijų, kelių NATO vykdomų operacijų ir iniciatyvų bei kitų Lietuvos sąjungininkų ir partnerių vykdomų operacijų ar mokymo misijų. Atsižvelgiant ị saugumo situaciją regione, Lietuvos karinio indèlio koncentracija ị keletą prioritetinių NATO, ES ir JT regionų tiketina ir toliau išliks, o ị kitas vyksiančias tarptautines operacijas ir misijas bus skiriama parama pagal galimybes.

NATO transformacija ir nauja „30-30-30-30“ iniciatyva, Europos Sajungos iniciatyva gynybos srityje - Europos taikos priemonè (angl. European Peace Facility), Jungtinès Karalystès vystoma Jungtinių ekspedicinių pajėgų (angl. Joint Expeditionary Forces; JEF) iniciatyva, Prancūzijos prezidento Emanuelio Makrono siūloma Europos intervencinè iniciatyva (angl. European Intervention Initiative), galimi Šiaurès Baltijos šalių bendradarbiavimo tarptautinèse operacijose projektai, greičiausiai, vis labiau darys įtaką Lietuvos priimamiems sprendimams ateityje dèl LK karių dalyvavimo tarptautinėse operacijose ir indèlio jose didinimo, siekiant užtikrinti tarptautinị saugumą ir stabilumą.

Lietuva, įstojusi i NATO, prisiemè tarptautinius ịsipareigojimus dèl dalyvavimo tarptautinèse operacijose, taip pat ísipareigojo gynybai skirti ne mažiau kaip 2 proc. nuo BVP. Net ir krizès laikotarpiu, kai finansavimas KAS gerokai sumažẻjo, Lietuva savo įsipareigojimus dèl dalyvavimo tarptautinèse operacijose išlaikè, o LK karių, dalyvaujančių tarptautinėse operacijose, skaičius buvo rekordinis. Pažymetina, kad KAS ištekliai - skiriami asignavimai ir žmogiškieji ištekliai - nors ir yra vienas svarbiausių veiksnių, tačiau ne vienintelis svarbių veiksnių kategorijoje, turinčių lemiamą reikšmę LR Seimui priimant sprendimą dèl LK karių dalyvavimo tarptautinèse operacijose. Darytina išvada, kad Lietuvos karių dalyvavimas tarptautinėse operacijose ir toliau išliks vienu iš Lietuvos užsienio ir gynybos politikos prioritetų, o didejjant PKT skaičiui ir KAS finansavimui gali vis labiau didèti sąjungininkų spaudimas didinti Lietuvos paramą tarptautinèms operacijoms. Nelaukdama sajungininkų spaudimo, Lietuva gali ir pati priimti sprendimą plèsti dalyvavimą tarptautinèse operacijose, siekdama turèti dar kokybiškesnę Lietuvos kariuomenę.

2017 m. LR Seimas prièmé nutarimą dèl Lietuvos karių ir civilių KAS tarnautojų dalyvavimo tarptautinèse operacijose 2018-2019 m., kuriuo padidino didžiausią Lietuvos karių ir civilių KAS tarnautojų, galinčių dalyvauti tarptautinèse operacijose, skaičių iki 255. Nors šis leidžiamas karių ir civilių 
KAS tarnautojų dalyvauti tarptautinėse operacijose skaičius yra beveik 2 kartus didesnis nei 2016 m., tačiau jis yra vis dar gerokai mažesnis nei 2006-2012 m., kai buvo leista dalyvauti tarptautinèse operacijose 420 karių ir civilių KAS tarnautojų. Tam tikrą lūži priimant sprendimus dèl faktinio LK karių dalyvavimo tarptautinèse operacijose galime jižvelgti ir LR Vyriausybès programos igyvendinimo plane, kuriame ịtvirtintas rodiklis, kad Lietuvos kariuomenès karių, dalyvaujančių tarptautinèse operacijose ir misijose $2016 \mathrm{~m}$., bus ne mažiau kaip 40, o $2020 \mathrm{~m}$. šis skaičius padidintas nuo $50 \mathrm{iki} 150^{58}$. Atsižvelgiant i turimą dalyvavimo tarptautinèse operacijose patirtį, didejjantị KAS finansavimą ir PKT karių skaičių, galima teigti, kad yra visos prielaidos ir galimybės Lietuvai artimiausioje ateityje didinti dalyvaujančių tarptautinėse operacijose karių skaičių iki 420.

Atsižvelgiant ị KAS skiriamus, turimus ir planuojamus išteklius (finansinius ir žmogiškuosius), dalyvavimo tarptautinèse operacijose patirtị, darytina prielaida, kad ilgalaikeje perspektyvoje dalyvavimas tarptautinèse operacijose ir Lietuvos karinis indèlis jose turètų nuosekliai didèti. Kita vertus, tie patys ištekliai išliks ypač svarbūs siekiant užtikrinti kariuomenès plètrą ir modernizaciją, prioritetinių sričių vystymą, kariuomenès pasirengimą ginkluotai valstybès gynybai, įskaitant sąveikos užtikrinimą su sąjungininkais, taip pat galimam visuotinès karo prievolès igyvendinimui. Dèl šios priežasties tinkamas finansavimas, išteklių paskirstymas ir aiškus KAS skirtų užduočių prioretizavimas tiesiogiai darys įtaką galimam karių skaičiaus didinimui tarptautinèse operacijose.

2017 m. birželis - 2018 gegužé

${ }^{58}$ Lietuvos Respublikos Vyriausybès nutarimas „Dèl Lietuvos Respublikos Vyriausybès programos igyvendinimo plano patvirtinimo“ (2017 m. kovo 13 d. Nr. 167 (aktuali redakcija)), 5.5.3. darbo rodiklis. 